\title{
АНАЛІЗ ГАПТИЧНИХ ЕЛЕМЕНТІВ ІНТРАОКУЛЯРНИХ ЛІНЗ
}

\author{
Поліщук О.С., аспірант \\ E_1_@ukr.net \\ Козяр В.В., доц. к.м.н. \\ kozyarvasiliy@gmail.com \\ Факультет біомедичної інженерії \\ Національний технічний університет \\ «Київський політехнічний інститут імені Ігоря Сікорського» \\ м. Київ, Україна
}

\begin{abstract}
Реферат -Після операчій, проведених по видаленню катаракти, в око людини імплантують інтраокулярну лінзу (ІОЛ). ІОЛ включає в себе оптичну частину (сама лінза) та гаптики, за допомогою яких вона правильно розмімується на місиі видаленого природнього кришталика. Гаптичні елементи повинні виконувати ряд важливих функцій: попередження дислокації лінзи, надання правильної форми капсульному мішку, захист капсули від розвитку вторинної катаракти. Для забезпечення цих та інших функиій, елементи кріплення (гаптика) має задовольняти умови як фізичних, так $і$ хімічних властивостей. B статі приведений аналіз існуючих гаптик інтраокулярних лінз та їх можливостей.
\end{abstract}

Ключові слова - Інтраокулярна лінза, итучний кришталик, гаптика, око, кришталик, дислокація, вторинна катаракта, капсульний мімок.

\section{I.ВСТУП}

Штучний кришталик - інтраокулярна лінза (ІОЛ) імплантується в око для заміни власного кришталика через причину його помутніння або $з$ метою хірургічної корекції аметропії[1,2]. Катаракта є причиною 33\% слабобачення і 51\% загальної світової сліпоти, причому 82\% всіх сліпих складають люди старше 50 років [3;4].Перша інтраокулярна лінза була зроблена $з$ жорсткого полімеру, яка за формою була точною копією природного кришталика. Винайшов іiі англійський офтальмолог Гарольд Рідлі, який зауважив що у пілотів Королівських ВПС, які мали проникаюче поранення ока уламками розбитого плексигласового ліхтаря, не виникає ніяких відторгнень.

В подальшому розвитку інтраокулярних лінз виділяють 5 поколінь[5]:

- 1949-1954 рр. - задньокамерна лінза 3 органічного скла;

- 1952-1962 pp. - передньокамерна інтраокулярна лінза;

- 1953-1973 рр. - інтраокулярна лінза 3 підтримкою на райдужці;

- 31963 p - сучасні варіанти передньокамерних інтраокулярних лінз.

- 31975 p - сучасні варіанти задньокамерних інтраокулярних лінз.
Нині, кожна інтраокулярна лінза складається з оптики (оптичної частини), яка забезпечує його основну функцію, а також фіксуючих (гаптичних) елементів, які дозволяють безпечно i надійно закріпити оптику, попереджаючи переміщення іiі в оці (Рис.1, Рис.2).

В даний час «золотим стандартом» катарактальної хірургії є факоемульсифікація катаракти через малий самогерметизуючий розріз з імплантацією в капсульний мішок задньокамерних інтраокулярних лінз $[6 ; 7$; 8].Імплантація ІОЛ для корекції афакіі має незаперечну перевагу для зорової реабілітації пацієнтів в порівнянні з афакічних окулярами або контактними лінзами [9;10].

Оптимальним місцем імплантації ІОЛ є капсульна сумка кришталика[11]. Однак, при неможливості імплантації ІОЛ в капсулу кришталика, лінза може бути розміщена в інших відділах ока - в передній камері, на райдужці, в задній камері поза капсульним мішком. Для можливості розміщення в усіх цих місцях, гаптика повинна мати відповідні параметрами і властивості.При цьому по нині в літературі немає достатньої доказової бази поперевазі того чи іншого способу фіксації [11].

На сьогоднішній день існує близько 1500 моделей ІОЛ, які виготовляються 33 фірмами по всьому світі [12]. В разі монолітної 
конструкції гаптики є продовженням лінзи i формуються із однакового з лінзою матеріалу (Рис.1). В іншому разі, гаптики приєднуються до лінзи як окремі елементи і виготовляються із матеріалів, відмінних від матеріалів лінзи. (Рис.2). Якщо вести мову стосовно переваги одного типу перед іншим, то можна встановити, що лінзи, які мають гаптику, як окремий елемент мають більшу схильність до їх відломлення, що може привести до серйозних проблем. Лікарі неодноразово відзначали випадки відриву опорних елементів від контура оптичного диска[12]

Не монолітні ІОЛ в більшості мають $\mathrm{C}$ та Jподібні гаптики (C-loop, J-loop), а також модифіковані, які досить часто виготовляються 3 поліпропіленової нитки 3 поперечним перерізом 100-150 мкм, (Рис.2). Поліпропілен має наступні фізико-механічні характеристики (табл.1).

Таблиця 1.Фізико-механічні властивості поліпропілену[13,14]

\begin{tabular}{|c|c|}
\hline Щільність, г / $\mathrm{cm}^{3}$ & $0,90-0,91$ \\
\hline $\begin{array}{c}\text { Руйнівна напруга при розтягуванні, } \\
\text { кгс } / \mathrm{cm}^{2}\end{array}$ & $250-400$ \\
\hline Відносне видовження при розриві,\% & $200-800$ \\
\hline $\begin{array}{c}\text { Коефіцієнт об'ємного розширення при } \\
20^{\circ} \mathrm{C}\end{array}$ & 0,00033 \\
\hline Модуль пружності при згині, кгс / см² & $6700-11900$ \\
\hline $\begin{array}{c}\text { Межа текучості при розтягуванні, кгс } \\
/ \text { см }^{2}\end{array}$ & $250-350$ \\
\hline $\begin{array}{c}\text { Вологопоглинання за } 30 \text { діб при } \\
20^{\circ} \mathrm{C}, \%\end{array}$ & 0,03 \\
\hline Твердість по Брінеллю, кгс / мм & $6,0-6,5$ \\
\hline
\end{tabular}

До матеріалу, 3 якого виготовляється як сама лінза так і гаптика висуваються наступні вимоги:

- біологічна інертність;

- хімічна стійкість протягом багатьох десятків років;

- відсутність канцерогенних властивостей;

- здатність формуватися або механічно оброблятися і приймати потрібну форму;

- можливість надійно стерилізуватись;

- $\quad$ мати високу прозорість;

- досить високий показник заломлення;

- мати низьку відносну щільність;

- зберігати оптичні умови на протязі не менше 50 років;
- спектр пропускаються променів повинен бути близьким до спектру природного кришталика.

За даними С. Н. Федорова та співавт., межа міцності прозорої передньою капсули катарактального кришталика - 7,6 г / мм², а

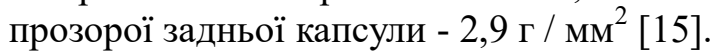

При дифузному помутнінні капсули катарактального кришталика іiі біомеханічні властивості різко знижуються незалежно від віку пацієнтів (межа міцності може становити

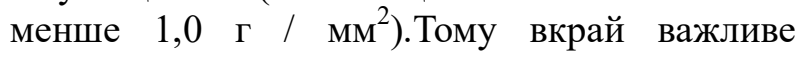
дотримання значення межі міціності капсули.

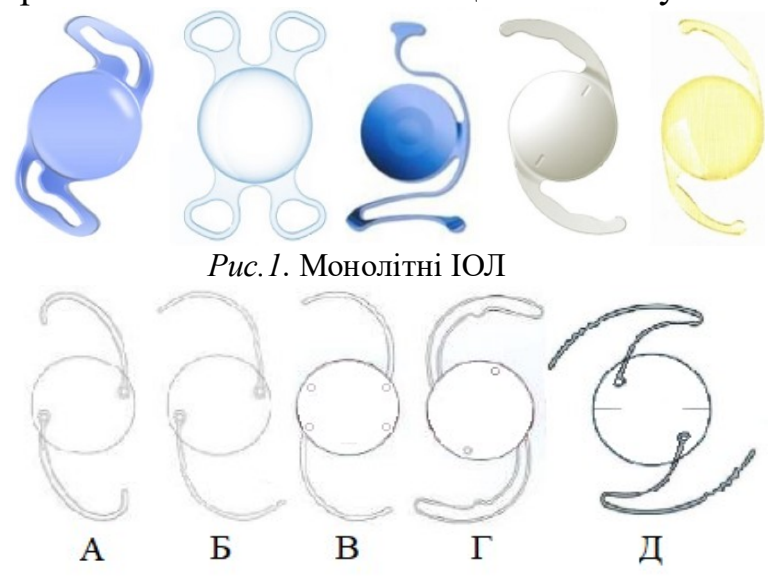

Рис.2. Види не монолітних лінз

А- Лінза з J-loop

Б, В- Лінза з C-loop

Г,Д- Лінза з модифікованою гаптикою

Лінзи, які використовують поліпропіленову нитку в якості гаптики, є жорсткими, а тому їхнє практичне застосування відходить в минуле. На зміну їм прийшли монолітні гнучкі лінзи 3 товщиною гаптичних елементі близько 0,42мм (Рис.1).

\section{ІІ. ОГЛЯД ЛІТЕРАТУРИ}

E. Stephansson i співавт. були проведені дослідження ІОЛ, опорні елементи яких виготовлялися 3 різних матеріалів (поліпропілен, силікон, поліамід, лавсан) [16].

В ході досліджень вивчали залежність пружної сили опорного елемента від діаметра поперечного перерізу, вплив кута кріплення опорних елементів на механічні властивості ІОЛ. Досліджували жорсткість опорного елемента при різної площі його контакту зі склепінням капсульного мішка кришталика. 
Виявлено, що пружна сила опорних елементів, виготовлених з поліаміду і лавсану, значно перевищує міцність капсули кришталика.

Виходячи 3 цього можна зробити висновок, що найбільш прийнятними матеріалами для виготовлення опорних частин ІОЛ слугують поліпропілен i силікон, так як механічні властивості цих матеріалів (таблиця 1 та 2 відповідно) не перевищують межі міцності капсульного мішка.

Таблиця 2.Фізико-механічні властивості силікону

\begin{tabular}{|c|c|}
\hline Щільність, г / $\mathrm{cm}^{3}$ & $1,52 \pm 0,03$ \\
\hline $\begin{array}{c}\text { Руйнівна напруга при розтягуванні, } \\
\text { кгс } / \mathrm{cm}^{2}\end{array}$ & $250-350$ \\
\hline Відносне видовження при розриві,\% & $200-1000$ \\
\hline $\begin{array}{c}\text { Коефіцієнт об'ємного розширення при } \\
20^{\circ} \mathrm{C}\end{array}$ & 0,00035 \\
\hline Модуль пружності при згині, кгс / см² & $8000-12000$ \\
\hline $\begin{array}{l}\text { Межа текучості при розтягуванні, кгс } \\
/ \text { cm }^{2}\end{array}$ & $250-350$ \\
\hline $\begin{array}{c}\text { Вологопоглинання за } 24 \text { год при } \\
20^{\circ} \mathrm{C}, \%\end{array}$ & 0,01 \\
\hline Твердість по Брінеллю, кгс / мм & $6,0-6,5$ \\
\hline
\end{tabular}

Зараз з'явилися нові силоксанові полімери, точніше олігомери з молекулярної масою до 100000 i акрильними функціональними групами на кінцях полімеру. Загальну формулу такого біфункціонального олігомера можна записати в такий спосіб[17,18]:

$\mathrm{R}-\mathrm{Si}\left(\mathrm{CH}_{3}\right) 2-\mathrm{O}-\left\{\left[\mathrm{Si}\left(\mathrm{CH}_{3}\right) 2-\mathrm{O}-\right] \mathrm{a}\right.$

[ $\left.\left.\mathrm{SiCH}_{3} \mathrm{C}_{6} \mathrm{H}_{5}\right] \mathrm{b}\right\} \mathrm{n}-\mathrm{Si}\left(\mathrm{CH}_{3}\right) 2-\mathrm{R}$, де

$\mathrm{R}-\mathrm{CH}_{2} \mathrm{OC}(\mathrm{O})-\mathrm{CH}=\mathrm{CH}_{2}$;

$\mathrm{a}=0,5-1,0$;

$\mathrm{b}=0-0,5$;

n - ціле число.

Помітно збільшився попит на пружноеластичні гідрофільні ІОЛ. Ці ІОЛ виготовляють 3 матеріалів, отриманих блоковою полімеризацією по радикальному механізму монометакрилового ефіру діетиленгліколю:

$$
\mathrm{CH}_{2}=\mathrm{C}\left(\mathrm{CH}_{3}\right)-\mathrm{C}(0)-0-\left(\mathrm{CH}_{2}\right)_{2}-\mathrm{OH}
$$

3 добавками біфункціональних мономерів, наприклад диметакрілового ефіру диетиленгліколю:

$\mathrm{CH}_{2}=\mathrm{C}\left(\mathrm{CH}-\mathrm{C}(0)-0-\left(\mathrm{CH}_{2}\right) 2-0-\mathrm{C}(0)-\right.$

$\mathrm{C}(\mathrm{CH} 3)=\mathrm{CH}_{2}$.
Еластичність цей матеріал набуває після набрякання у воді, тому для таких матеріалів вводять поняття як, вологопоглинання, коефіцієнт набухання і показники заломлення світла до набрякання і після набухання. Не дивлячись на безліч переваг силікону, як еластичність, невагомість в камерній волозі, стійкість до біологічної деструкції, задовільні фізико-механічні властивості, досі не повністю вирішене питання про його токсичності, i багато авторів відзначають післяопераційні запалення, пов'язані 3 впливом матеріалу на тканини ока.

\section{III. МЕТА ДОСЛІДЖЕННЯ}

Огляд та класифікація різних видів гаптичних елементів інтраокулярних лінз, дослідження їх властивостей, матеріалів, способу виготовлення та можливостей.

\section{IV. МАТЕРІАЛИ ДОСЛІДЖЕНЬ}

Інтраокулярні лінзи різних виробників 3 різними фізичними та хімічними властивостями, функціями, матеріалами та кількістю гаптичних елементів.

\section{V. РЕЗУЛЬТАТИ ТА ОБГОВОРЕННЯ}

Велика увага приділяється дизайну гаптики, адже від неї залежить не тільки правильність роботи оптичного апарату, а й відсутність післяопераційних ускладнень. У випадку, коли гаптичні елементи частково або повністю не виконують свої функції, інтраокулярна лінза може скрутитись, зміститись (дислокація), “випасти” в скловидне тіло, цим самим набути аберацій різних порядків. Під силою земного тяжіння, ІОЛ прямує до низу, що в разі недостатньої пружності гаптик призводить до зміщення оптичної вісі світлозломлюючих структур ока.

Гаптика може бути різної форми з різними конструктивними параметрами. Мати в собі додаткові отвори та елементи, які слугують маркерами для хірурга, та надають можливість для додаткової фіксації (в більшості випадків шовної), іридосклеральної і райдужної (рис.3). 


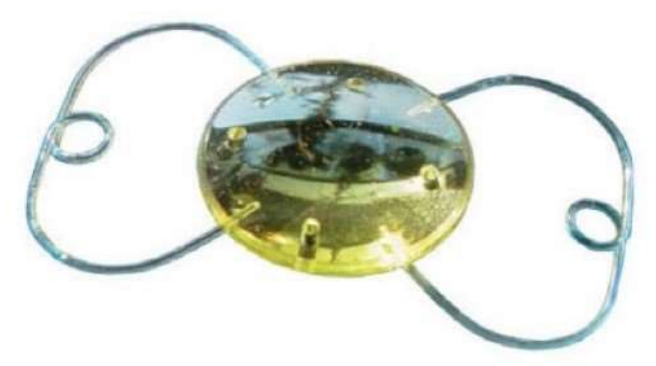

Puc.3.Інтраокулярна лінза з гаптикою, яка дозволяє провести іридосклеральну фіксацію

Кількість гаптичних елементів варіюється 2, 3, 4 та більше. Ведуться дискусії, яка кількість є оптимальною. Нажаль, віддати перевагу тій чи іншій неможливо. Загальний діаметр інтраокулярних лінз знаходиться в межах від 9.5 мм до 14,5 мм, що пояснюється індивідуальністю розмірів природнього кришталика та розмаїттям технічних рішень.

По розміщенню гаптики розрізняють:

- Неангульовану (планарну) гаптику (лінза і гаптика лежать в одній площині, Рис.4,А).

- Ангульовану гаптику (якщо вона розміщується під кутом до площини лінзи, Рис.4,Б).

- Торсіонну гаптику (гаптика, яка має пружньо-деформовані властивості, Рис. 4, В)
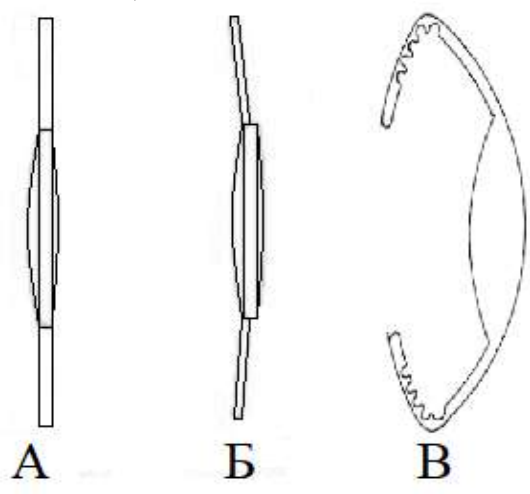

Puc.4. Види нахилу гаптики відносно лінзи

Дослідження показали, що ангульована та торсіонна гаптикамають переваги над неангульваною [19,20], що заключаються в наданні капсулі кришталика фізіологічної форми та можливості захисту задньої капсули кришталика від розвитку вторинної катаракти.
Досягнення оптимальних результатів для ІОЛ можуть бути 3 дотримання наступних умов[17]:

- для рівномірного розподілу тиску опорних елементів на капсулу кришталика площа їх контакту повинна становити не менше 1/3 окружності капсульного зводу кришталика;

- оптимальний кут нахилу опорних елементів повинен бути 8-12;

- кут кріплення опорних елементів до оптичної частини лінзи повинен бути більше $50^{\circ}$;

- для полегшення введення ІОЛ в капсулу кришталика i забезпечення стабільності в ній бажано використовувати ІОЛ з відкритими опорними елементами.

За характером взаємодії ІОЛ 3 капсулою кришталика, дослідники виділяють три категорії задньокамерних лінз[21]:

- I категорія - оптимальні конструкції, жорсткість опорних елементів не перевищує

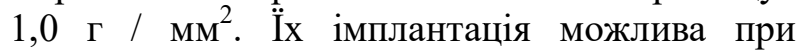
наявності не тільки збереженій, але i дистрофічно зміненої капсули кришталика.

- II категорія - група ризику, жорсткість опорних елементів знаходиться в межах 1,03,0 г / мм². Імплантація їх в капсульний мішок можлива тільки при наявності задньої капсули кришталика.

- III категорія- група протипоказання, жорсткість опорних елементів більше 3,0 г / м $^{2}$, що значно перевищу жорсткість задньої капсули кришталика i тому такий тип інтраокулярних лінз не рекомендований для імплантації.

\section{VI. ВИСНОВКИ}

Гаптичні елементи ІОЛ відіграють важливу роль, адже вони забезпечують правильність розташування лінзи в оці людини, попереджують виникнення аберацій у зв'язку 3 дислокацією лінзи та зморщенням капсули кришталика. В післяопераційному періоді ангульована та торсіонна гаптика краще захищає капсулу кришталика від розвитку вторинної катаракти.

Монолітні інтраокулярні лінзи менш схильні до появи проблем, пов'язаних 3 
відломленням гаптик, а також, в більшості випадків, вони більш гнучкі, за рахунок малого розміру їх імплантація в око полегшена, що зменшує операційний стрес ока в цілому.

Щодо фізико-механічних властивостей матеріалів, а також щодо біомеханічних властивостей капсули кришталика ока людини, згідно даних наведених в статті, найбільш відповідним матеріалом для виготовлення гаптичних елементів, є силікон та поліпропілен.

\section{ПЕРЕЛІК ПОСИЛАНЬ}

[1] Евграфов В.Ю. Катаракта. М.: Медицина, 2005. 368 c.

[2] Шкарлова С. К. Глаукома и катаракта. Ростов н/Д: Феникс, 2001. 191 с.

[3] Pascolini, D. Global estimate sofvisual impairment: 2010 / D. Pascolini, S. P Mariotti // Br. J. Ophthalmol. 2011. - № 3. - P. 134-144.

[4] Stevens, G. A. Global prevalence of vision impairment and blindness / G. A. Stevens [etal.] // Ophthalmology. 2013. - N. 120. - P. 2377-2384.

[5] Bellan The evolution of Cataract Surgery: The Most Common Eye Procedure in Older Adults / L. Bellan // Geriatrics and Aging. - 2008. - №11(6). - P. 328-332.

[6] Азнабаев, Б. М. Клинические результаты ультразвуковой факоэмульсификации на основе трёхмерных колебаний / Б. М. Азнабаев, Т. Р. Мухамадеев, Т. И. Дибаев [с соавт.] // Современные технологии в офтальмологии. - 2015. - № 4 (8). - С. 11-13.

[7] Малюгин, Б. Э. Современные стандарты хирургии катаракты с имплантацией интраокулярной линзы (обзор литературы) / Б. Э. Малюгин, А. В. Терещенко, Ю. А. Белый [и др.] // Рефракционная хирургия и офтальмология. - 2010. - № 10 (3). - С. 4-10.

[8] Alio, J. L. MICS (microincision cataract surgery) // J. L. Alió, P. Klonowski, L. Rodriguez-Prats, eds. et al. // Mastering the techniques of advanced phaco surgery. New Delhi :Jaypee Brothers Medical Publishers LTD, 2008. - P. 121-136.

[9] Bhutto, I. A. Visual outcome and complications in Abexterno sclera fixation IOL in aphakia in pediatric age group/ I. A. Bhutto, G. Q. Kazi, P. S. Mahar, U. A. Qidwai // Pak. J. Med. Sci.- 2013. - Vol. 29 (4). - P. 947-950.

[10] Малюгин, Б. Э. Проблемы хирургического лечения катаракты и интраокулярной коррекции афакии по результатам 20-летней работы МНТК «Микрохирургия глаза» / Б. Э. Малюгин, Э. В. Егорова, В. Г. Копаева, А. И. Толчинская // Офтальмохирургия. - 2007. - № 1. - С. 10-16.

[11] Apple D.J., Peng Q., Vesessook N. et al. Eradicationofposteriorcapsuleopacification: documentationofamarked decrease in Nd:YAG laser posterior capsulotomy rates noted in an analysis of 5416 pseudophakic human eyes obtained postmortem // Ophthalmology. - 2001. - Vol. 108. - P.505-518.

[12] Азнабаев Б. М. Ультразвуковая хирургиякатаракты - факоэмульсификация. М.: Август Борг, 2005. $129 \mathrm{c}$.

[13] Перепёлкин В. П. Полипропилен, его свойства и методы переработки. - Л.: ЛДНТП, 1963. — 256 с.

[14] Кренцель Б. А., Л. Г. Сидорова. Полипропилен. Киев.: Техника, 1964. - 89 с.

[15] Федоров С. Н., Круглякова Г. М., Болдаева Э. В. Заднекамернаяинтраокулярнаякоррекциятравматиче ских катаракта и афакій Офтальмохирургия. - 1991. — № 2. - С. 3-9.

[16] Сэнфорд Д., Гилберт Д., Гербердинг Д., Сэнде М. Антимикробнаятерапия. - М., 1996. - С. 219.

[17] Рускол И.Ю., Алексеева Е.И. и др. Оптически прозрачные фотоотверждаемые кремнийорганические композиции // Клеи. Герметики. Технологии. № 12, С.10-15, 2007.

[18] Emmanuel Pouget, Jeff Tonnar, at al. WellArchitectures Poly (dimetilsiloxane) - Containing Copolymers Obtained by Radical Chemistry//Chem. Rev. 2010, 110, 1233-1277.

[19] Finoll O, Buehl W, Menapace R, Georgopoulos M, Rainer G, Siegl H, Kaider A, Pinz A. Comparison of 4 methods for quantifying posterior capsule opacification // J Cataract Refract Surg. - 2003. - Vol. 29. - № 1. - P . 106-111.

[20] Nishi O. Nishi K, Mano C. Et al. The inhibition of lens epitelial cell migration by a discontinuous capsula bend created by a band-shaped circular loop or a capsulabanding ring // Ophthalmic SurgLazerz. - 1998. - Vol. 29. - P. 119-125.

[21] Даниличева В.Ф. Современная офтальмология: Руководство. 2-е изд. / Под ред. В. Ф. Даниличева. СПб.: Питер, $2009 . \quad-688$ с. 


\title{
АНАЛИЗ ГАПТИЧЕСКИХ ЭЛЕМЕНТОВ ИНТРАОКУЛЯРНЫХ ЛИНЗ
}

\author{
Полищук А.С., аспирант \\ E_1_@ukr.net \\ Козяр В.В., ДОц. к.м.н. \\ kozyarvasiliy@gmail.com \\ Факультет біомедичнои инженерии \\ Национальный технический университет \\ «Киевский политехнический інститут шимени Игоря Сикорского» \\ г. Киев, Украина
}

\begin{abstract}
Реферат -После операцій проведенных по удалениюкатаракты в глаз человека имплантируютинтраокулярнуюлинзу(ИОЛ). ИОЛ включает в себя оптическую часть (сама линза) и гаптику с помощью которой она правильно размещается в месте удаленного естественного хрусталика. Гаптические элементы должны выполнять ряд важних функиий: предупреждение дислокачии линзы, предоставления правильной формы капсульном мешку, защитить капсуль от развития вторичной катаракты. Для обеспечения этих и других функций, элемент крепления (гаптики) должно удовлетворять условия как физических, так и химических свойств. В статье приведено аналіз существующей гаплики интраокулярных линз и их возможностей.
\end{abstract}

Ключевые слова -Интраокулярналинза, искусственный хрусталик, гаптики, глаз, ИОЛ, хрусталик, дислокация, вторичная катаракта, капсульный мешок.

UDC 617.741.4-004.1: 681.7.066.2: 681.7.066.3

\section{THE ANALYSIS OF HATIC ELEMENTS OF THE INTRAOCULAR LENS}

\author{
Polischuk O.S., PhD student \\ E1@ukr.net \\ KozyarV.V., Assoc. Ph.D. \\ kozyarvasiliy@gmail.com \\ Faculty of Biomedical Engineering \\ National Technical University of Ukraine \\ "Igor Sikorsky Kyiv Polytechnic Institute" \\ Kyiv, Ukraine
}

\begin{abstract}
After operations performed toremovecataracts, anintraocularlens (IOL) isimplanted into the humaneye. The IOL includes the optical part (thelens) and the haptic with whichitisproper lyplaced intheplace of the removed naturallens. Hapticelements mustper form a number of important functions: preventing the dislocation of the lens, providing the corrects hape of the capsulebag, protecting the capsule from the development of secondary cataracts. To ensurethese and other functions, fasteningelements (haptics) mustsatisfy the conditions of both physical and chemical properties. The article provide sananalysis of theexisting hapticintraocular lenses and the iropportunities.
\end{abstract}

Key words - Intraocular lens, artificial lens, haptic, eye, IOL, lens, dislocation, secondary cataract, capsular bag. 